\title{
Bledius Leach from southern Brazil (Coleoptera, Staphylinidae, Oxytelinae) ${ }^{1}$
}

\author{
Edilson Caron² \& Cibele Stramare Ribeiro-Costa ${ }^{2}$
}

${ }^{1}$ Contribution $n^{\circ} 1725$ of the Departamento de Zoologia, Universidade Federal do Paraná, Brazil.

${ }^{2}$ Laboratório de Sistemática e Bioecologia de Coleoptera (Insecta), Departamento de Zoologia, Universidade Federal do Paraná, Caixa Postal 19020, 81531-980 Curitiba-PR, Brazil. CNPq fellowships. caron@ufpr.br; stra@ufpr.br

ABSTRACT. Bledius Leach from southern Brazil (Coleoptera, Staphylinidae, Oxytelinae). Three species of Bledius
Leach, 1819 are recognized from southern Brazil. A new species is described, B. hermani n. sp., from Paraná and Rio
Grande do Sul States and B. fernandezi Bernhauer, 1939 is redescribed. The geographical distribution of B. bonariensis
Bernhauer, 1912 and B. fernandezi are extended. A key to identification of Bledius from southern Brazil is also provided.

KEYWORDS. Neotropical region; new species; ocean beaches; rove beetles; taxonomy.

RESUMO. Bledius Leach do sul do Brasil (Coleoptera, Staphylinidae, Oxytelinae). Três espécies de Bledius Leach, 1819 são reconhecidas do sul do Brasil. Uma nova espécie é descrita, B. hermani sp. nov., proveniente dos estados do Paraná e Rio Grande do Sul e B. fernandezi Bernhauer, 1939 é redescrita. A distribuição geográfica de B. bonariensis Bernhauer, 1912 e B. fernandezi são estendidas. Uma chave para identificação de Bledius do sul do Brasil também é apresentada.

PALAVRAS-CHAVE. Espécie nova; estafilinídeos; praias oceânicas; região Neotropical; taxonomia.

The species of Bledius Leach, 1819 live in unvegetated, sunny and moist sand adjacent to rivers, lakes and oceans, where they feed on algae and diatoms. Both adults and larvae make burrows in the soil and can be detected by the cast or tumulus left on surface above the entrance of the burrows. Some seacoastal species live in the intertidal zone, and they remain in the burrow during high tide, in an air bubble. An extensive report about the natural history of the genus is found in Herman (1986).

Bledius comprises 462 species worldwide (Herman, pers. comm.) placed in 34 species groups, of which seven are in the Neotropical region (mandibularis, aequatorialis, emarginatus, semiferrugineus, forcipatus, punctatissimus and bonariensis groups) (Herman 1986).

Herman (2001), in his world catalog of the Staphylinidae, listed ten Bledius species from Brazil, but only B. bonariensis Bernhauer, 1912 was reported from southern Brazil, Rio Grande do Sul; the other nine species are from the north and west in Amazonas and Mato Grosso States. However, in studies focusing on the ecology of the Atlantic beaches in southern Brazil, three species (B. bonariensis, B. fernandezi Bernhauer, 1939, and B. microcephalus Fauvel, 1901) have been reported (Gianuca 1997; Barros et al. 2001; Schreiner \& Ozorio 2003).

The aim of this paper is to characterize the Bledius fauna from southern Brazil and to provide a key. This paper also includes a description, a redescription and new geographical records for Bledius.

\section{MATERIALAND METHODS}

Specimens are deposited in the American Museum of Natural History, New York, United States (AMNH); The Natural History Museum, London, England (BMNH); Coleção de
Entomologia Pe. J.S. Moure, Departamento de Zoologia, Universidade Federal do Paraná, Curitiba, Brazil (DZUP); Field Museum of Natural History, Chicago, United States (FMNH); Museu de Ciências Naturais da Fundação Zoo-Botânica do Rio Grande do Sul, Porto Alegre, Brazil (MCNZ); Museo de La Plata, La Plata, Argentina (MLP); Museu Nacional, Universidade Federal do Rio de Janeiro, Rio de Janeiro, Brazil (MNRJ); and Museu de Zoologia, Universidade de São Paulo, São Paulo, Brazil (MZSP).

Dried specimens were first macerated in boiling water for five minutes then cleared in boiling $10 \% \mathrm{KOH}$ for two minutes. The dissection was carried out under the stereoscopic microscope Zeiss Stemi SV6 and the drawings made with the same equipment and also with an optical microscope Zeiss Standard 20 with a drawing tube attached. Photographs were taken using a stereoscopic microscope Leica MZ 16 with a Leica DFC 500 digital camera. The images were captured with computer software IM 50 (Image Manager) and combined using the image processing software Auto-Montage Pro (Syncroscopy). The final art of drawings and photographs were performed in Adobe Photoshop software, version 7.0.

Measurements were done using the micrometric ocular in the stereoscopic microscope Wild M5. The following abbreviations were used: BL, body length (from anterior margin of head to posterior margin of tergite VIII); BW, body width (across humeral region); PL, pronotum length (maximum); PW, pronotum width (maximum); EL, elytron length (maximum).

The terminology adopted was that of Blackwelder (1936) and Herman $(1970,1986)$.

\section{RESULTS ANDDISCUSSION}

There are three species of Bledius from southern Brazil, 
which belong to bonariensis and punctatissimus groups following Herman's classification (Herman 1986).

Key to the species of Bledius from southern Brazil

1. Head with supraantennal ridge extended anteriorly into a broad horn (male longer than female) (Figs. 1, 2, 8); pronotum with an abrupt constriction near the base (Figs. 1,9)

..... (bonariensis group) B. bonariensis Bernhauer, 1912

Head with supraantennal ridge not extended anteriorly (Figs. 3-7, 10, 17); pronotum without abrupt constriction near the base (Figs. 13, 19) .... (punctatissimus group) 2

2. Procoxal fissure closed (Fig. 14); elytra golden yellow with basal dark brown spot extending postero-medially into a lighter color (Fig. 3); tergum VIII with posterior margin emarginated (Fig. 15) ..... B. fernandezi Bernhauer, 1939

Procoxal fissure open (Fig. 20); elytra pale yellow with basal and usually subapical median brownish spot (Figs. 5, 7); tergum VIII with posterior margin truncate (Fig. 22) B. hermani n.sp.

\section{Bledius bonariensis Bernhauer, 1912}

(Figs. 1, 2, 8, 9, 24)

Bledius (Hesperophilus) bonariensis Bernhauer, 1912: 168 (original description).

Bledius bonariensis Scheerpeltz, 1933: 1112 (world catalog); Blackwelder, 1944: 106 (Neotropical checklist); Herman, 1970: 376 (world checklist); Herman, 1986: 228-231 (redescription, illustrations, map distribution, bonariensis group), 300 (world checklist); Herman, 2001: 1545 (world catalog).

Description. See Herman (1986).

Distribution (Fig. 24). Old records: ARGENTINA: Buenos Aires, San Clemente; URUGUAY: Rocha, Atlantica; and BRAZIL: Rio Grande do Sul, Rio Grande (Praia do Cassino) (Herman 1986).

New records: BRAZIL: Paraná, Guaraqueçaba (Ilha das Peças and Ilha do Superagui).

Examined Material. BRASIL, Paraná, Guaraqueçaba, Ilha das Peças, 23-III-2005, Rosa col. (3 DZUP); same locality, 12.IV.2005, Matuella col. (3 DZUP); Guaraqueçaba, Ilha do Superagui, 02-VII-2007, Caron \& Martins col. (27 DZUP). Rio Grande do Sul, Rio Grande, Praia do Cassino, 26-IV-1991, Gianuca col. (1 DZUP); same locality and collector, 6-I-1993 (15 MZSP); 13-I-1993 (22 DZUP); 20-I-1993 (10 DZUP); 27-I-1993 (32 DZUP); 3-II-1993 (6 DZUP); 10-II-1993 (43 DZUP); 13-III-1993 (1 DZUP).

Remarks. The bonariensis group includes only $B$. bonariensis, which is distinguished from other species of the genus mainly by head with subantennal pockets (Herman 1986: 230, Fig. 441). From the Southern Brazilian species, $B$. bonariensis also can be separated by the supraantennal ridge of the head that is extended anteriorly into a broad horn (Figs. $1,2,8)$, pronotum with an abrupt constriction near the base (Figs. 1, 9), labrum with a median incision (Herman 1986: 230, Fig. 442), closed procoxal fissure (Herman 1986: 230, Fig. 449), truncate posterior margin of tergum VIII and the absence of lateral lobes of the aedeagus (Herman 1986: 231, Figs. 451, 452).

Males of $B$. bonariensis have a more strongly developed supraantenal ridge than females, the mandibles are tridentate and the second denticle is enlarged (Herman 1986: 230, Fig. 445). The mandibles of the females are quadridentate (Herman 1986: 230, Fig. 443).

\section{Bledius fernandezi Bernhauer, 1939}

(Figs. 3, 4, 10-16, 24)

Bledius (Hesperophilus) fernandezi Bernhauer, 1939: 234 (original description).

Bledius fernandezi Blackwelder, 1944: 106 (Neotropical checklist); Herman, 1970: 377 (world checklist); Herman, 1986: 216 (punctatissimus group), 307 (world checklist); Herman, 2001: 1545 (world catalog); Fernandez et al. 2007: 29 (catalog of types at Museo de La Plata).

Redescription. Male. BL: 2.36-2.80 mm, BW: 0.52-0.60 mm.

Body dark brown with antennae and legs yellowish brown (Figs. 3, 4); antenna with scape and segments 8-11 dark brown; elytra golden yellow with basal dark brown spot extending postero-medially into a lighter color. Body subcylindrical and densely covered with vestiture of fine microsetae. Dorsum of head, pronotum and elytra with microgranulate sculpturing.

Clypeus with anterior margin slightly rounded (Fig. 10). Epistomal suture broadly arcuate. Antenna with segments 711 increasingly wide and forming somewhat a club (Fig. 11), last segment two times the length of 10. Labrum transverse, anterior margin deeply sinuate, each cuticular process of internal fringe of epipharyngeal lobes with serrated apex (Fig. 12). Mandibles tridentate. Submentum extending onto venter of head, posterior margin slightly V-shaped. Pronotum convex (Fig. 4), wider than long (PW/PL: 1.23) (Fig. 13), anterior angles produced, posterior margin curved, prototergosternal suture present (Fig. 14), procoxal fissure closed, protrochantin concealed. Elytra longer than wide (El/BW: 2.33), elytral epipleural ridge complete. Sternite VII with posterior margin truncate. Tergite VIII with posterior margin broadly emarginated (Fig. 15). Aedeagus follows pattern of punctatissimus group with lateral lobes slender, cylindrical and reaching apex of median lobe; median lobe bulbous.

Female. Similar to male. Spermatheca with base wider than apex (Fig.16).

Type material: The type material of B. fernandezi is deposited in the FMNH and was seen by Dr Alfred F. Newton who confirmed the material here studied is similar to the type specimen of $B$. fernandezi. There is also one type specimen deposited at MLP (Fernandez et al. 2007).

Distribution (Fig. 24). Old records: URUGUAY: Canelones (Herman 1986).

New Records: BRAZIL: Paraná, Guaraqueçaba (Ilha do Superagui); Rio Grande do Sul, Rio Grande (Praia do Cassino).

Examined material. BRASIL, Paraná, Guaraqueçaba, Ilha do Superagui, 02-VII-2007, Caron \& Martins col. (3 DZUP). Rio Grande 

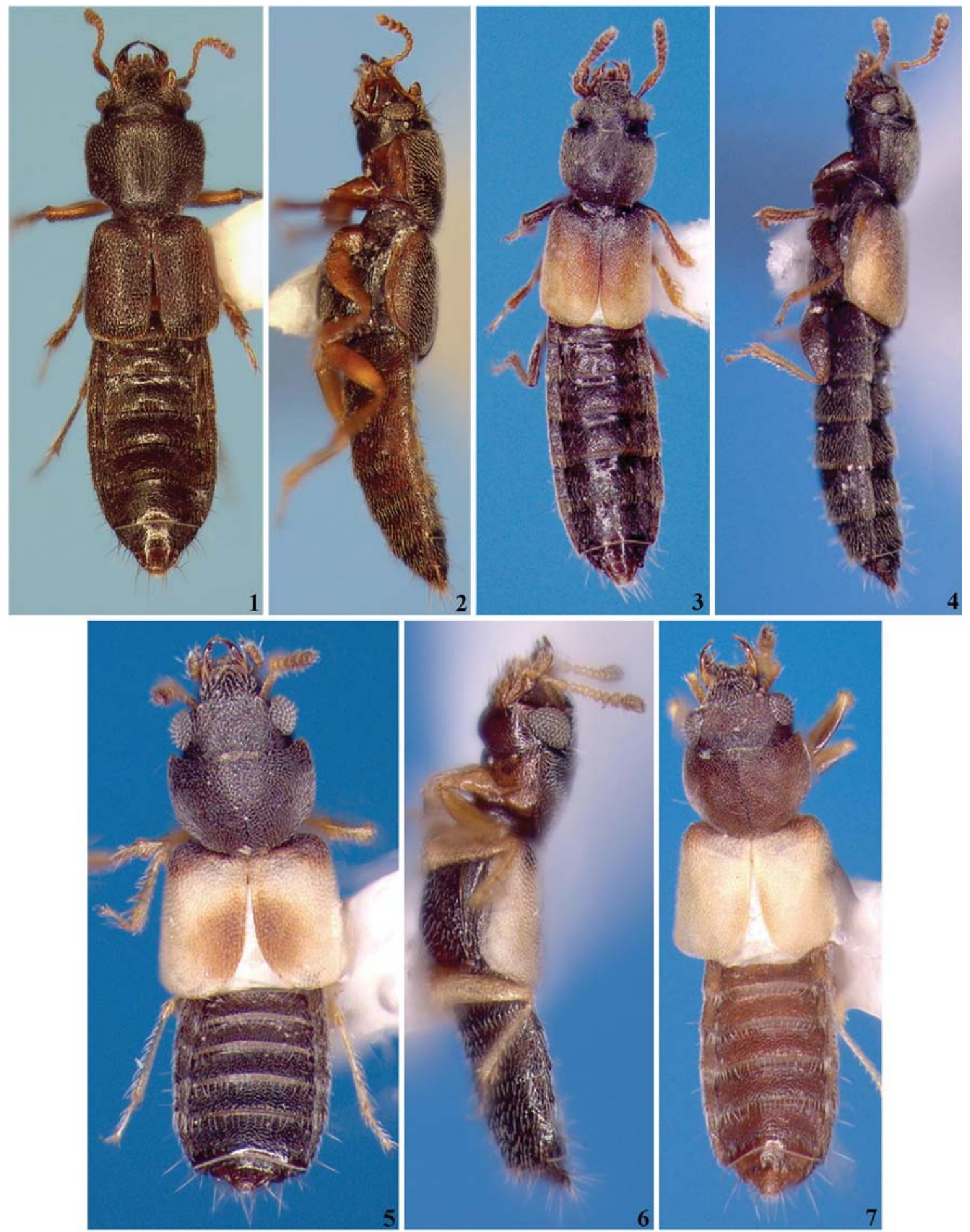

Figs. 1-7. Bledius from Southern Brazil. 1, 2. B. bonariensis: 1. dorsal view; 2. lateral view. 3, 4. B. fernandezi: 3. dorsal view; 4. lateral view. 57. B. hermani n. sp.: 5, 7. dorsal view; 6. lateral view.

do Sul, Rio Grande, Praia do Cassino, 26-IV-1991, Gianuca col. (26 DZUP); same locality and collector, 29-V-1991 (7 AMNH); 6-I-1993 (15 DZUP); 13-I-1993 (11 MZSP); 20-I-1993 (41 DZUP); 27-I-1993 (29 DZUP); 10-II-1993 (43 DZUP); 13-III-1993 (61 DZUP).

Remarks. Bledius fernandezi is included in the punctatissimus group together with other 25 species worldwide
(Herman 1986). This species is very similar to Nearctic and Neotropical B. punctatissimus LeConte, 1877; for both each cuticular process of the internal fringes of the epipharyngeal lobes has a serrated apex (compare Fig. 12 with Herman 1972: 142, Fig. 78), the procoxal fissure is closed (Fig. 14), the posterior margin of tergite VIII is broadly emarginate (Fig. 15) 
and the posterior margin of sternite VII of males is truncate (absence of the sexual dimorphism). Bledius fernandezi differs from B. punctatissimus mainly by body size, B. punctatissimus is longer, 2.6-3.7mm (Herman 1972); the anterior margin of the clypeus is slightly rounded (Fig. 10), but in B. punctatissimus the clypeus is shallowly emarginate (Herman 1972); and the anterior pronotal angles are produced (Fig. 13), but not in $B$. punctatissimus (Herman 1972).

Bledius fernandezi differs from B. hermani n. sp., another species of the punctatissimus group from Southern Brazil, mainly by the closed procoxal fissure (Fig. 14), which is open in B. hermani n. sp. (Fig. 20); the golden yellow elytra with the basal dark brown spot extending postero-medially into a lighter color (Fig. 3), the elytra of B. hermani n. sp. are pale yellow with a basal and usually subapical median brownish spot (Fig. $5,7)$; and the posterior margin of tergite VIII is broadly emarginate (Fig. 15), but truncate in B. hermani n. sp. (Fig. 22). Moreover, for $B$. fernandezi the apex of each cuticular process of the internal fringe of the epipharyngeal lobes is serrated (Fig. 12), in B. hermani n. sp. they are not serrated (Fig. 18); and in males the posterior margin of sternite VII is truncate (absence of the sexual dimorphism), in B. hermani $\mathbf{n}$. sp. sternite VII of the males has a median lobe on the posterior margin (Fig. 21).

\section{Bledius hermani $\mathbf{n} . \mathbf{s p .}$}

(Figs. 5-7, 17-24)

Description. Male. BL: 1.76-1.84 mm, BW: 0.50-0.58 mm. Body reddish brown to dark brown with antennae, maxilla,
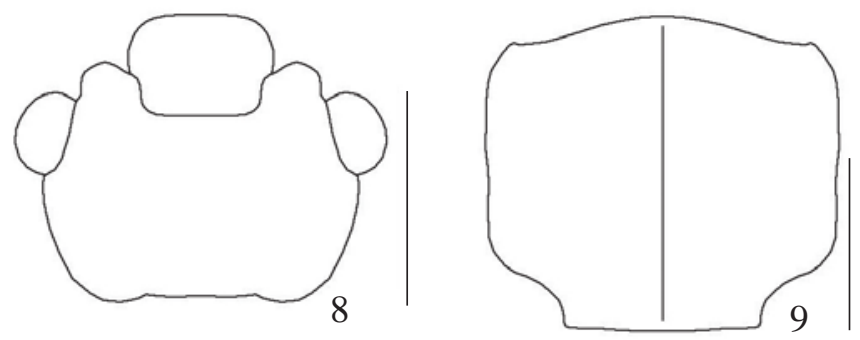

Figs. 8-9. Bledius bonariensis: 8. head, setae removed; 9. pronotum, setae removed. Scales. $0.25 \mathrm{~mm}$.

labium and legs yellowish (Figs. 5-7); antenna with scape and 9-11 or only last segment brownish; elytra pale yellow with basal and usually subapical median brownish spot. Body subcylindrical and densely covered with vestiture of fine microsetae. Dorsum of head, pronotum and elytra with microgranulate sculpturing.

Clypeus with anterior margin slightly sinuate (Fig. 17). Epistomal suture broadly arcuate. Antennae with segments 711 increasingly wide and forming somewhat a club, last segment two times the length of 10. Labrum transverse (Fig. 18), anterior margin slightly sinuate. Mandibles tridentate. Submentum extending onto venter of head, posterior margin strongly V-shaped. Pronotum convex (Fig. 6), wider than long (PW/PL: 1.45) (Fig. 19), anterior angles produced, posterior margin curved, prototergosternal suture present (Fig. 20), procoxal fissure open, protrochantin exposed. Elytra longer

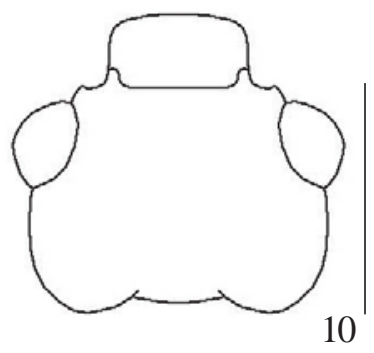

10
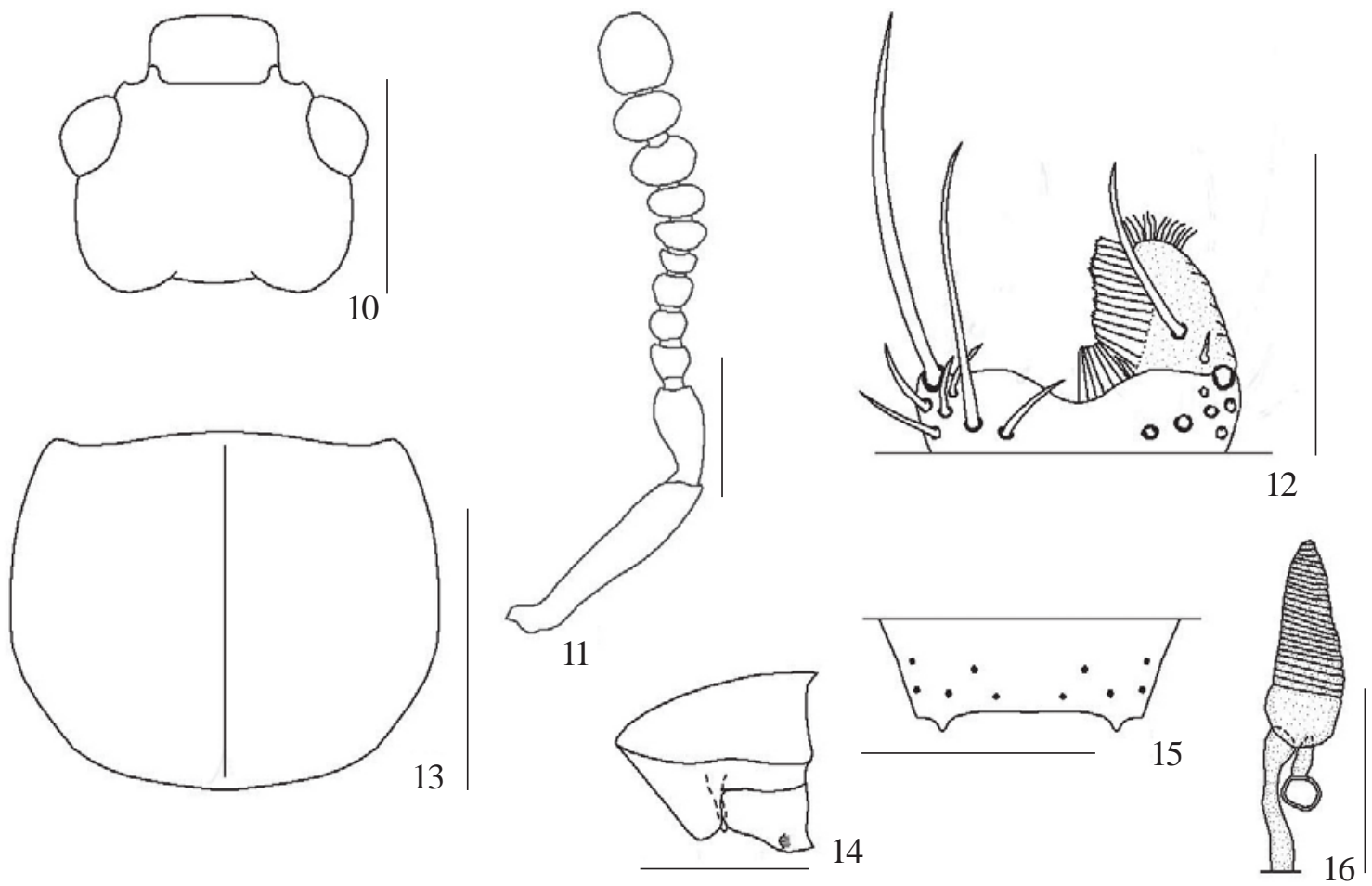

Figs. 10-16. Bledius fernandezi: 10. head, setae removed; 11. antenna, setae removed; 12. labrum, left epipharyngeal lobe and right setae of labrum removed; 13. pronotum, dorsal view, setae removed; 14. prothorax, lateral view, setae removed; 15 . tergite VIII, setae removed; 16. spermatheca. Scales. 10, 13-15: $0.25 \mathrm{~mm} ; 11,12,16: 0.15 \mathrm{~mm}$. 


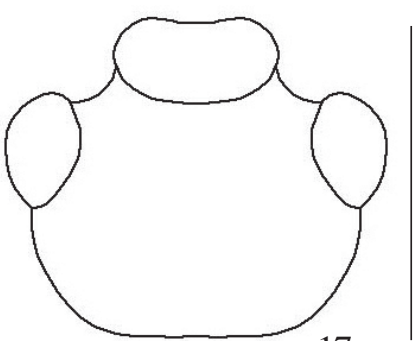

17

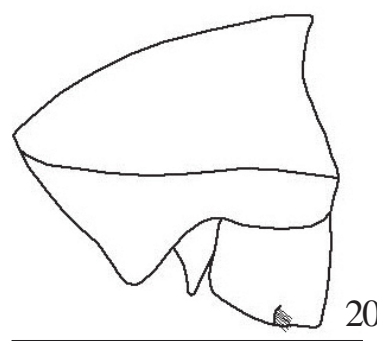

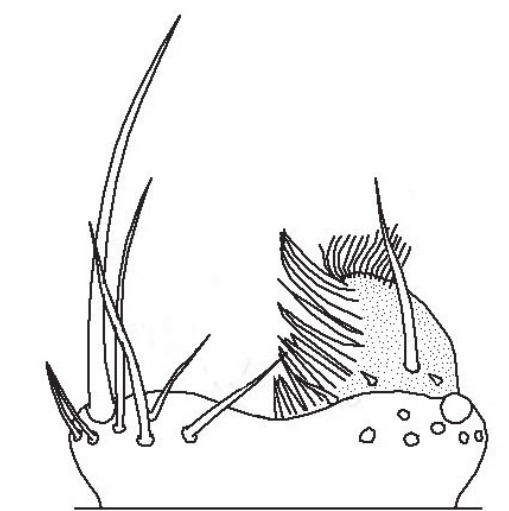

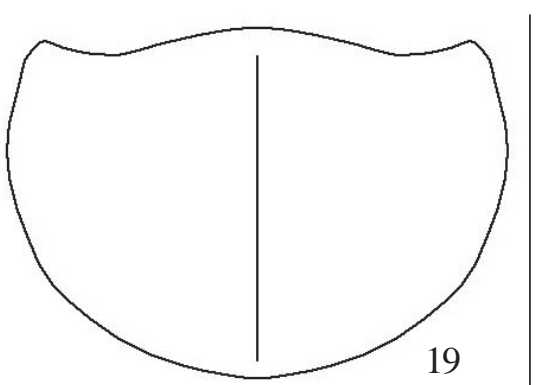

19

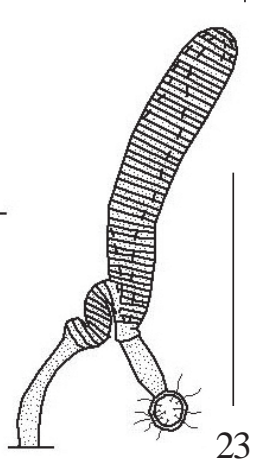

Figs. 17-23. Bledius hermani n. sp.: 17. head, setae removed; 18. labrum, left epipharyngeal lobe and right setae of labrum removed; 19 pronotum, setae removed; 20. prothorax, lateral view, setae removed; 21. sternite VII, male, fine microsetae and left prominent setae removed; 22. tergite VIII, setae removed; 23. spermatheca. Scales. 17, 19-22: $0.25 \mathrm{~mm}$; 18, 23: $0.15 \mathrm{~mm}$.

than wide (El/BW: 1.86), elytral epipleural ridge present and complete. Sternite VII with median lobe on posterior margin (Fig. 21). Tergite VIII with posterior margin truncate (Fig. 22). Aedeagus follows pattern of punctatissimus group (see $B$. fernandezi).

Female. Similar to male except posterior margin of sternite VII truncate, without median lobe. Spermatheca with annelidoid form and fine setae around of the apex of the accessory gland (Fig. 23).

Distribution. BRAZIL: Paraná, Guaraqueçaba (Ilha do Superagui, Ilha da Peças, Ilha do Mel) and Rio Grande do Sul, Rio Grande (Praia do Cassino) (Fig. 24).

Type Material. Holotype. Male. BRASIL, Paraná, Guaraqueçaba, Superagui, 20-IX-2006, Borzone col. (DZUP). 434 paratypes: 1 male, 1 female and 274 sex undetermined with the same label information of the holotype (10 sex undetermined, AMNH; 10 sex undetermined, BMNH; 1 male, 1 female and 204 sex undetermined, DZUP; 10 sex undetermined, FMNH; 10 sex undetermined, MCNZ; 10 sex undetermined, MLP; 10 sex undetermined, MNRJ; 10 sex undetermined, MZSP); 79 sex undetermined differing only by the date, 21-XI-2006 (DZUP); 10 sex undetermined differing only by the data, 02-VII-2007, Caron \& Martins col. (DZUP). Guaraqueçaba, Ilha das Peças, 12.IV.2005, Matuella col. (1 sex undetermined, DZUP); same locality, 22.III.2005, da Rosa col. (1 sex undetermined DZUP); Guaraqueçaba, Ilha do Mel (Brasilia), 04.VIII.2005, Aluizio col. (6 sex undetermined, DZUP); same locality and collector, 04.X.2005 (1 sex undetermined, DZUP). Rio Grande do Sul, Rio Grande, Praia do Cassino, 13-I-1993, Gianuca col. (5 sex undetermined, AMNH; 5 sex undetermined, BMNH; 1 male, 3 females and 21 sex undetermined, DZUP; 9 sex undetermined, FMNH; 5 sex undetermined, MNRJ; 5 sex undetermined, MZSP); and 3 differing only by date, 10-II-1993 (1 male, 1 female and 1 sex undetermined, DZUP).
Etymology. The species name is in honor to Dr Lee Herman, from AMNH, for his valuable contributions to the knowledge of Bledius.

Remarks. Intraspecific variation was observed in material collected from Paraná and Rio Grande do Sul States. Specimens from Paraná are usually darker (Figs. 5, 6), antennal segments 9-11 are brownish and the elytra have basal and subapical median brownish spots. In contrast, specimens from Rio Grande do Sul are lighter (Fig. 7), the antenna has only the last segment

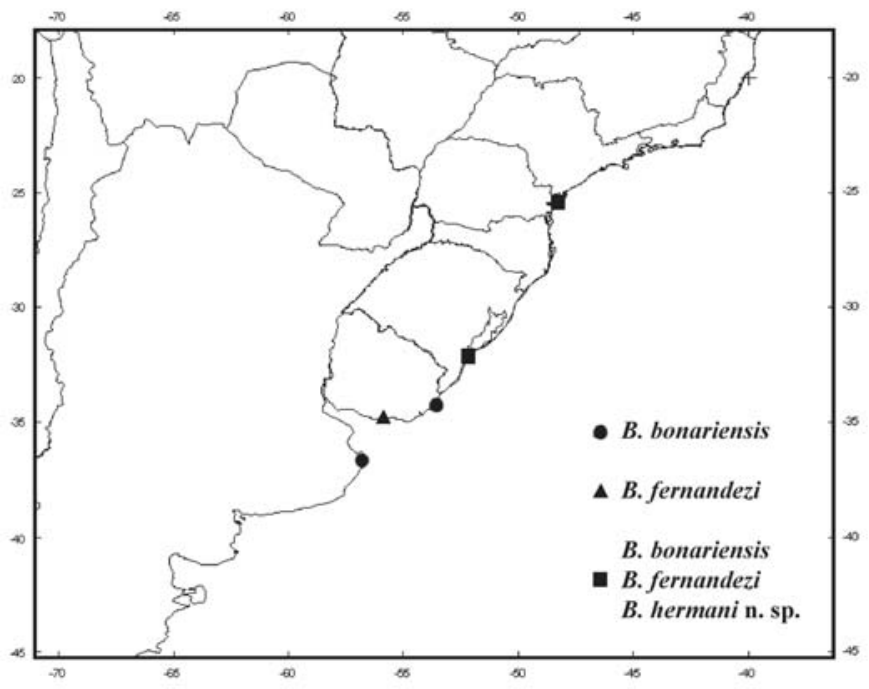

Fig. 24. Distribution of Bledius species from southern Brazil. 
brownish and the elytra have a smaller and evanescent subapical spot that is lighter than the basal.

The annelidoid spermatheca of $B$. hermani $\mathbf{n}$. sp. places it within the punctatissimus group, and among all species of this group it is very similar to Bledius caribbeanus Blackwelder, 1943, from West Indies. Differences can be found mainly in body size, B. caribbeanus is longer, 1.7-2.5mm (Herman 1972); the pale yellow elytra with a basal and usually subapical median brownish spot (Figs. 5, 6), whereas the elytra are entirely black in B. caribbeanus (Herman 1972); and sternite VII has eight prominent setae arranged in a transverse row near the apex, but $B$. caribbeanus has only two (compare Fig. 21 with Herman 1972: 143, Fig. 93).

Differences between $B$. hermani n. sp. and B. fernandezi are listed under remarks of $B$. fernandezi.

Final Considerations. This study reports three species, $B$. bonariensis, B. fernandezi and a new species, B. hermani n. sp. from southern Brazil. All of them occur in the Atlantic beaches and have similar distribution (Fig. 24). During July 2007, B. bonariensis, B. fernandezi and B. hermani n. sp. were sympatric at Ilha do Superagui, Paraná State (pers. obs. of the first author).

Gianuca (1997) was the only author to record $B$. microcephalus for southern Brazil, Rio Grande do Sul. Herman (2001) registered this species in Colombia and Trinidad, on the Caribbean seacoast. The specimens that Gianuca (1997) called as $B$. microcephalus probable were a misidentification of $B$. hermani n. sp. since he had already recognized $B$. bonariensis and B. fernandezi in his samples.

Acknowledgments. We wish to thank Dr Carla de Lima Bicho (Universidade Federal do Paraná, UFPR), Dr Carlos Alberto Borzone and Ana Luiza Gandara Martins (Centro de Estudos do Mar, CEMUFPR), and M.Sc. Leonardo Cruz da Rosa (Fundação Universidade Federal do Rio Grande, FURG) for the specimens; Dr Alfred F. Newton (FMNH) for type comparison of B. fernandezi; Dr Lee Herman (AMNH) for the valuable suggestions on the manuscript; The Biological Collection Network of Paraná (Taxon-line, UFPR) for the photographs; and the Conselho Nacional de Desenvolvimento Científico e Tecnológico $(\mathrm{CNPq})$ for the fellowships for the authors.

\section{REFERENCES}

Barros F.; C. A. Borzone \& S. Rosso. 2001. Macroinfauna of six beaches near Guaratuba bay southern Brazil. Brazilian Archives of Biology and Technology 44: 351-364.

Bernhauer, M. 1912. Zur Staphylinidenfauna von Südamerika. Entomologische Blätter 8: 167-179.

Bernhauer, M. 1939. Zur Staphylinidenfauna Argentiniens und Brasiliens (Col.). Revista de Entomología 10: 231-249.

Blackwelder, R. E. 1936. Morphology of the coleopterous family Staphylinidae. Smithsonian Miscellaneous Collections 94: $1-102$.

Blackwelder, R. E. 1944. Checklist of the Coleopterous Insects of Mexico, Central America, The West Indies, and South America. Part 1. United States National Museum Bulletin 185: xii + $1-188$.

Fernandez, L. A.; N. Cabrera; M. C. Posse \& C. Gabellone. 2007. Catalog of the types of Staphylinidae (Insecta, Coleoptera) deposited at Museo de La Plata (Argentina). Zootaxa 1611: 2544.

Gianuca, N. M. 1997. Coastal Foredune Fauna, p. 102-104. In: Seeliger, U.; C. Odebrecht \& J.P. Castello (Eds.). Subtropical convergence environments: the coast and sea in the southwestern Atlantic. Berlin, Springer-Verlag, Heidelberg, 308 p.

Herman, L. H. 1970. Phylogeny and reclassification of the genera of the rove-beetle subfamily Oxytelinae of the World (Coleoptera, Staphylinidae). Bulletin of the American Museum of Natural History 142: 343-454.

Herman, L. H. 1972. Revision of Bledius and related genera. Part I. The aequatorialis, mandibularis, and semiferrugineus groups and two new genera (Coleoptera, Staphylinidae, Oxytelinae). Bulletin of the American Museum of Natural History 149: 111-254.

Herman, L. H. 1986. Revision of Bledius. Part IV. Classification of species groups, phylogeny, natural history, and catalogue (Coleoptera, Staphylinidae, Oxytelinae). Bulletin of the American Museum of Natural History 184: 1-368.

Herman, L. H. 2001. Catalog of the Staphylinidae (Insecta: Coleoptera) 1758 to the end of the second millennium, parts I-VII. Bulletin of the American Museum of Natural History 167: 1-4218.

Scheerpeltz, O. 1933. Staphylinidae VII, p. 989-1500. In: S. Schenkling (Ed.). Coleopterorum Catalogus, 6 (129), Berlin, Junk, 1881p.

Schreiner, R. \& C. P. Ozorio. 2003. Dinâmica da fauna de insetos do supralitoral numa praia do Atlântico Sul: Estudo de curta duração. Biociências 11: 123-131. 